\title{
PENILAIAN TINGKAT SERVICE TOKO ONLINE DAN ANALISIS PERBANDINGAN PERCEIVED PERFORMANCE
}

\author{
Sasa Ani Arnomo \\ Universitas Putera Batam, Indonesia.
}

\section{INFORMASI ARTIKEL}

Diterima Redaksi: 5 Agustus 2018

Diterbitkan Online: 30 September 2018

\section{KATA KUNCI}

Performance, Service, Online,

Ecommerce

\section{KORESPONDENSI}

E-mail: sasaupb@gmail.com

\begin{abstract}
A B $\mathbf{S}$ T $\mathbf{R}$ A $\mathbf{C}$ T
The sale and purchase transaction process are carried out through the internet using internet media using both smartphones and computers. The development of the internet has undergone a product sale and purchase transaction process. Various buying and buying transactions can only be done face-to-face, now it can be done through the internet called online stores. To support the freedom of online stores, a website or smartphone application is an important component that presents information in the form of text, images, sounds and others that are presented to find information in tracing and exploring information virtually on certain media. Many online sales websites will be seen from different levels of service. Therefore, the purpose of this analysis is to assess the performance of online store websites. The research method used in this study is a quantitative descriptive research method with comparative analysis techniques. The results obtained from the level of online store service levels show that the percentage of satisfaction is $64.09 \%$ and an increase in performance perceptions occur because each online store has different features and different times.
\end{abstract}

\section{Latar Belakang}

Perkembangan teknologi komputer dan jaringan internet telah menambah perubahan pada toko online, dengan munculnya beragam teknologi keamanan, teknologi pembayaran online, perangkat-perangkat mobile (smartphone, tablet), makin banyaknya organisasi dan pengguna yang terhubung ke internet, dan munculnya berbagai teknologi pengembangan aplikasi berbasis web. Pengguna internet meningkat di masyarakat yang telah mencapai 47,6\% pengguna dalam menggunakan perangkat mobile mereka dalam mengakses internet. Penyebab dari faktor ini adalah pengguna smartphone yang mencapai 71 juta orang dari 217.8 juta populasi penduduk Indonesia[1]. Toko

http://ejournal.upbatam.ac.id/index.php/cbis online didefinisikan sebagai semua bentuk proses pertukaran informasi antara organisasi dan stakeholder berbasiskan media elektronik yang terhubung ke jaringan internet. Transaksi online shopping berpengaruh signifikan dan positif terhadap kepuasan konsumen pada Ecommerce[2].

Internet merupakan salah satu implementasi dari teknologi komunikasi dan informasi yang menawarkan kecanggihan, kepraktisan dan kemudahan. Saat ini internet tidak hanya digunakan untuk mencari informasi dan berkomunikasi, tetapi dengan bantuan internet, setiap orang mendapatkan banyak kemudahan dalam aktivitas pembelian produk[3]. Pencarian informasi produk di internet dapat dilakukan 
dengan mengunjungi website yang berhubungan dengan informasi yang dibutuhkan. Perkembangan internet telah mempermudah proses transaksi jual beli produk. Berbagai transaksi jual beli yang sebelumnya hanya bisa dilakukan dengan tatap muka, kini sudah dapat dilakukan melalui internet yang disebut dengan toko online. Untuk menunjang kehadiran toko online, website merupakan salah satu komponen penting yang menyajikan informasi dalam bentuk teks, gambar, suara dan lain-lain yang dipresentasikan kepada pencari informasi dalam menelusuri dan memperoleh informasi secara virtual tanpa terikat pada media tertentu. Para pengguna internet yang ingin berbelanja secara online pasti akan mengunjungi website terlebih dahulu dan setelah itu akan memilih produk yang ingin dibeli.

Berdasarkan data survei Asosiasi Penyelenggara Jasa Internet Indonesia (APJII) pada tahun 2017 bahwa pengguna internet di Indonesia mencapai 88.1 juta orang, dengan jumlah tersebut penetrasi internet di Indonesia tahun 2014 adalah sebesar 34.9\%. Dari total pengguna internet tersebut, sebesar $27 \%$ atau sekitar 23.8 juta pengguna internet yang melakukan belanja online. Media atau jenis perangkat yang dipakai untuk mengakses internet yaitu smartphone sebanyak 85\%, laptop atau netbook sebanyak 32\%, tablet sebanyak 13\% dan personal computer sebanyak 14\%. Angka pengguna internet itu tidak lepas dari pantauan berbisnis melalui internet, salah satu contohnya adalah perusahaan toko online. Adapun grafiknya:

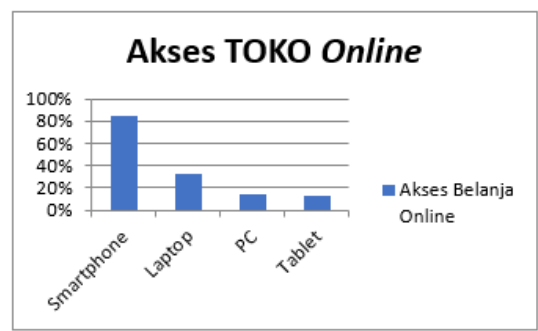

Gambar 1.1 Akses Toko Online

Toko online atau bisa disebut dengan perdagangan elektronik atau e-dagang adalah proses pembelian dan penjualan produk yang dilakukan secara elektronik dengan memanfaatkan jaringan internet komputer. Toko online melibatkan proses transaksi, pengolahan produk, pengenalan sistem penjualan dan pembelian produk. E-commerce dapat membantu http://ejournal.upbatam.ac.id/index.php/cbis proses kerja dan proses transaksi antara penjual dan pembeli menjadi lebih menghemat waktu dan dapat menghubungkan jarak penjual dan pembeli yang jauh. Dengan adanya toko online, penjual dapat lebih mengefektifkan waktu, tempat dan tanpa harus bertatapan langsung dengan pembeli ataupun sebaliknya. Dari segi waktu, pembeli dapat memesan produk pada saat kapanpun yang mereka inginkan dan penjual dapat melihat jumlah pemesanan produk tanpa harus selalu menunggu pembeli mengunjungi toko. Dari segi tempat, pembeli yang berada di lokasi jauh tidak harus datang langsung untuk membeli produk dan jasa yang diinginkan, pembeli dapat langsung memesan di website dan produk yang dibeli akan diantarkan melalui jasa pengiriman.

Dalam dunia perdagangan global saat ini, transaksi elektronik adalah suatu hal yang tidak mungkin terhindarkan. Toko online adalah suatu contoh produk dari kemajuan teknologi informasi, dimana transaksi bisnis tidak lagi dilakukan secara konvensional. Toko online tidak mengharuskan pembeli berinteraksi langsung dengan penjual (secara fisik) dan tidak mengharuskan pembeli membayar menggunakan uang tunai (cash). Tetapi penjual diwakili oleh suatu sistem yang melayani pembeli secara online dengan melalui media jaringan komputer. Dalam melakukan transaksi, pembeli "berhadapan" dan berkomunikasi dengan sistem yang "mewakili" penjual. Dalam suatu situs toko online, website merupakan hal penting yang harus diperhatikan dimana sebuah website harus benar-benar menfasilitasi calon pembeli dalam melakukan suatu pembelian. Setiap website toko online memiliki sistem penjualan yang berbeda, baik dari cara menyampaikan informasi produk, proses pemesanan, metode pembayaran serta proses pemenuhan pesanan dalam mengirimkan produk kepada pembeli. Saat ini website toko online yang menjadi tren di Indonesia karena kemudahan untuk mengakses website tersebut adalah forum jual beli Kaskus, situs Olx, situs Lazada, situs Zalora, bukalapak, blanja dan lain-lain.

Berdasarkan data dari Asosiasi Ecommerce Indonesia (IDEA) tahun 2017, sebagian besar pelaku transaksi toko online adalah secara online, yang masih mendominasi transaksi bisnis fashion. Sebagian besar pembeli mengakui bahwa berbelanja 
produk fashion melalui toko online lebih mudah walaupun tidak bisa melihat secara langsung. Hal ini terungkap dalam survei bisnis toko online yang dilakukan Asosiasi Ecommerce Indonesia (IDEA). Dalam survei ini sekitar $78 \%$ calon pembeli yang lebih memilih berbelanja fashion melalui toko online. Angka ini di atas transaksi barang lainnya seperti handphone yang mencapai $46 \%$, peralatan elektronik lainnya mencapai $43 \%$, buku dan majalah mencapai 39\% dan bahan makanan yang mencapai 24\%. Berdasarkan latar belakang tersebut, penulis melakukan penelitian bagaimana menilai tingkat service toko online dan analisis perbandingan perceived performance website toko online.

\section{Kajian Literatur}

A. E-commerce Melalui Toko Online

E-commerce dapat didefinisikan sebagai penyebaran, pembelian, penjualan, pemasaran barang dan jasa melalui sistem elektronik seperti internet, televisi, web, atau jaringan komputer lainnya. Perdagangan melaui online juga disebut sebagai toko online merupakan istilah untuk semua jenis bisnis, atau transaksi komersial, yang melibatkan transfer informasi di Internet[4]. Terkadang toko online selain penjualan atau pembelian produk juga melakakukan transaksi jasa.

Perdagangan elektronik mencakup transaksi pembellian secara transfer dana via jaringan komputer. Pemilik situs web e-commerce di satu sisi memikirkan cara menarik lebih banyak pelanggan dan cara membuat pengunjung merasa aman saat berbelanja di situs[5]. Untuk lebih menunjukkan sinergi yang diperoleh dari perdagangan elektronik, kita akan melihat lebih jauh pada 5 (lima) proses yang harus dilewati sebelum seseorang memutuskan akan membeli produk atau jasa yang perusahaan tawarkan. Toko online mempunyai lima proses yaitu berbagi informasi, pemesanan, pembayaran, pemenuhan pemesanan, serta dukungan terhadap konsumen (customer service and support). Ada beberapa cara pengelompokan transaksi toko online salah satunya adalah dengan melihat sifat partisipan dalam transaksi toko online. Tiga kelompok besar toko online adalah sebagai berikut[6]:

1. Business-to-consumerE-commerce (B2C)
Penjualan produk dan jasa secara elektronik secara langsung kepada konsumen individu. Mencakup produk-produk retail dan jasa untuk para konsumen individu. Contohnya: Barners \& Noble.com, yang menjual buku, perangkat lunak dan music kepada konsumen.

2. Business-to-business E-commerce (B2B)

Penjualan barang dan jasa secara elektronik antar bisnis. Mencakup penjualan barang-barang dan jasa anatar bisni. Contohnya: Milpro.com, Milacron Inc, Web Site yang menjual alat-alat potong, roda gerinda dan alat-alat berat kelebih dari 100.000 bisnis mesin kelas kecil.

3. Consumere-to-consumere E-commerce (C2C)

Penjualan barang dan jasa secara elektronik antar konsumen. Mencakup konsumen yang menjual secara langsung kepada konsumen. Misalnya eBay, Web Site, Raksasa penyedia jasa lelang, memungkinkan orang=orang menjual barang-barang ke konsumen lain dengan cara melelangnya.

Ada beberapa faktor yang mempengaruhi kunci sukses dalam toko online dalam banyak kasus, sebuah perusahaan toko online bisa bertahan tidak hanya mengandalkan kekuatan produk saja, tapi dengan adanya tim manajemen yang handal, pengiriman yang tepat waktu, pelayanan yang bagus, struktur organisasi bisnis yang baik, jaringan infrastruktur dan keamanan, desain situs web yang bagus, beberapa faktor yang termasuk yaitu[6]: (1)Menyediakan jasa pembelian yang tanggap, cepat, dan ramah. (2)Menyediakan informasi barang dan jasa yang lengkap dan jelas. (3)Menyediakan banyak bonus seperti kupon, penawaran istimewa, dan diskon. (4)Menyediakan rasa komunitas untuk berdiskusi, masukan dari pelanggan. (5)Mempermudah kegiatan perdagangan, pemanfaatan internet dalam bisnis juga mengakibatkan proses bisnis berlangsung cepat.

\section{B. Transaksi pada Toko online}

Toko online memiliki alur umum yang melibatkan penjual, pengguna, teknologiteknologi pendukung, dan koneksi jaringan komputer di dalamnya. Alur ini dimulai dari pembeli yang terhubung ke server layanan dan aplikasi toko online melalui koneksi jaringan internet dan menggunakan aplikasi perantara, misalkan aplikasi web browser. Kemudian pembeli melakukan login ke dalam sistem atau melakukan pendaftaran terlebih dahulu. 
Sistem di dalam toko online akan melakukan penyimpanan data pendaftaran dan verifikasi pendaftaran (termasuk juga verifikasi login ke dalam sistem).

Selanjutnya setelah informasi mengenai pembeli diperoleh oleh sistem, kemudian pembeli melakukan proses pencarian barang atau produk yang diinginkannya pada katalog online yang disediakan oleh toko online. Disediakan keranjang belanja virtual untuk membantu pembeli online di dalam memilih dan meletakkan produk yang diinginkannya. Selanjutnya dilakukan proses pembayaran secara elektronik oleh pembeli kepada sistem yang menangani masalah pembayaran pada website toko online ini. Kemudian dilakukan kontak dengan layanan yang diberikan oleh bank (yang digunakan oleh pembeli untuk melakukan pembayaran). Setelah melakukan pembayaran beserta dengan data pengiriman atau alamat tujuan pengiriman, maka proses berbelanja online sudah dapat dikatakan selesai dengan baik. Pembeli cukup menunggu barang pesanan sampai dengan alamat pengiriman. Pembeli dan penjual sama-sama memiliki bukti digital untuk transaksi yang telah disepakati tersebut, untuk menjaga kepercayaan, keamanan dan kenyamanan masing- masing.

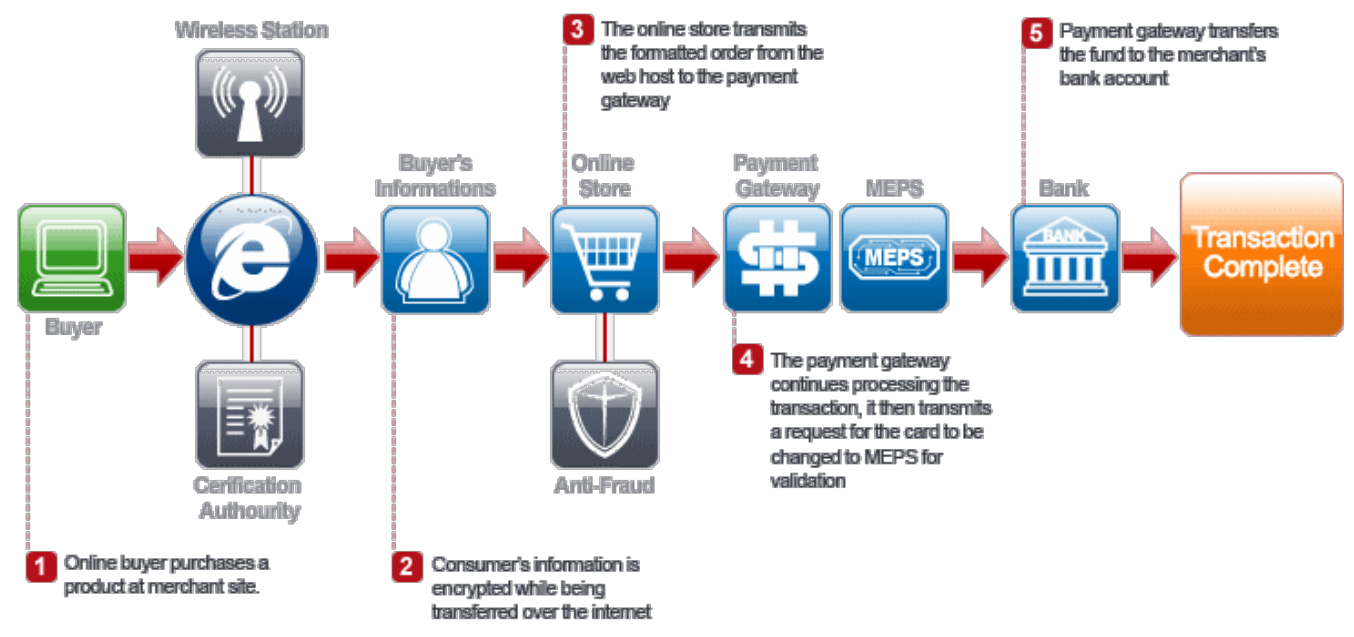

Gambar 2.1. Alur pada toko online

Beberapa kegiatan utama yang biasa dilakukan dalam toko online, yaitu sebagai berikut[7]: (1)Promosi. Promosi produk dan jasa sebuah perusahaan pada umumnya dimasukkan ke dalam iklan yang dipasang pada beberapa website terkenal. (2)Pemesanan. Pembeli dapat melakukan pemesanan terhadap suatu produk ataupun sekedar mendapatkan informasi mengenai produk yang diinginkannya melalui website. (3)Pembayaran. Pembeli melakukan pembayaran produk yang telah dipesan melalui metode pembayaran yang telah dipilih sebelumnya, seperti melalui transfer ke rekening bank, pembayaran di tempat (cash on delivery), melalui kartu kredit atau melalui layanan escrow, seperti PayPal. (4)Pengiriman produk. Pembelian produk digital, seperti perangkat lunak dan music dapat diunduh secara langsung melalui website setelah melakukan pembayaran. Namun, pengiriman produk yang tidak digital, seperti buku, baju, alat olahraga, dan lain sebagainya, bergantung kepada perusahaan yang menyelenggarakan penjualan barang-barang tersebut. (5)Layanan setelah pembelian. Layanan konsumen setelah pembelian adalah rantai terakhir dari keseluruhan proses bisnis antara perusahaan dan pembeli. Pembeli dapat mengirimkan e-mail kepada layanan pembeli dan perusahaan dapat mengembangkan sebuah knowledge based system untuk membantu para konsumen dalam mencari solusi dari permasalahan pembeli.

\section{Faktor Keberhasilan Toko Online}

Dalam menciptakan perusahaan toko online yang sukses, maka perusahaan harus mencari cara untuk dapat membangun kepuasan, 
loyalitas, dan hubungan baik dengan para pembeli secara online agar pembeli kembali melakukan pembelian pada website toko online[8]. Ketakutan konsumen terhadap risiko tidak ada pengiriman berdampak negatif terhadap belanja online[9]. Terdapat beberapa faktor sukses toko online atau toko online sebagai berikut: (1)Selection and value, faktor pilihan dan nilai meliputi pilihan produk yang menarik, harga yang bersaing, jaminan kepuasan, dan dukungan pelanggan setelah penjualan. (2)Performance and service, faktor kinerja dan pelayanan meliputi navigasi, proses belanja, dan pembelian serta konfirmasi pengiriman yang cepat dan mudah. (3)Look and feel, faktor tampilan dan rasa yakni meliputi pajangan web, situs web, area belanja, produk multimedia, halaman katalog dan fitur belanja yang menarik. (4)Advertising and incentives, faktor iklan dan insentif meliputi web dan promosi e-mail bersasaran serta penawaran khusus, termasuk iklan di berbagai situs afiliasi. (5)Personal attention, faktor perhatian personal meliputi halaman web personal, saran produk yang dipersonalisasi, iklan web dan pemberitahuan e-mail, serta dukungan interaktif untuk semua pelanggan. (6)Community relationship, faktor hubungan dengan komunitas meliputi komunitas virtual para pembeli, pemasok, perwakilan perusahaan dan lain- lainnya melalui newsgroup, ruang bincang, serta berbagai hubungan ke situs- situs terkait. (7)Security and reliability, faktor keamanan dan keandalan meliputi keamanan informasi pembeli dan transaksi di situs web, informasi produk yang dapat dipercaya, serta pemenuhan pesanan yang dapat diandalkan.

D. Peluang Penggunaan Toko online

Berikut adalah beberapa hal yang dapat menjadikan toko online sebagai sebuah peluang yang sangat menjanjikan terutama dalam hal transaksi penjualan dalam dunia digital [10] adalah sebagai berikut: (1)Menambah pembeli. (2)Memperluas area pemasaran produk. (3)Meningkatkan merk (brand). (4)Biaya hosting web (domain) yang lebih murah daripada biaya sewa toko dalam bentuk fisik, hal ini dapat menurunkan tingkat biaya operasional. (5)Kemudahan dalam hal pemesanan produk karena dapat dilakukan kapanpun dan dimanapun oleh masing-masing pembeli. (6)Kemudahan dalam hal pembayaran tanpa perlu menggunakan uang tunai, melainkan pembayaran transfer via Automatic Teller Machine (ATM). Menggunakan bantuan pihak ketiga, dan penggunaan kartu kredit. (7)Kemudahan dalam akses memperoleh informasi produk tanpa perlu mendatangi lokasi toko.

\section{Metodologi}

Data yang diperoleh melalui prosedur pengumpulan data, selanjutnya dianalisis dengan menggunakan uji validitas dan uji reliabilitas. Dalam penelitian ini, teknik pengumpulan data yang digunakan adalah kuesioner, sehingga perlu melakukan uji validitas dan uji reliabilitas terhadap kuesioner yang digunakan untuk mengetahui apakah kuesioner tersebut valid dan reliabel. Kemudian data diolah menggunakan analisis komparatif atau analisis perbedaan yaitu suatu analisis yang digunakan perbedaan antara dua variabel (data) atau lebih. Uji statistik yang digunakan untuk menganalisis apakah ada perbedaan antara dua kelompok data, tergantung dari jenis data yang digunakan. Jenis analisis komparatif terbagi dua, yaitu analisis komparatif untuk dua variabel (sampel) dan analisis komparatif untuk lebih dari dua variabel/sampel ( $\mathrm{k}$ sampel). Jenis analisis komparatif tersebut dapat dibedakan dengan sampel berkolerasi (dependent) dan sampel tidak berkolerasi (independent). Kelompok sampel dikatakan berkolerasi apabila sampel-sampel yang menjadi objek penelitian tidak dapat dipisahkan secara tegas, artinya anggota sampel kelompok pertama ada yang menjadi anggota sampel kelompok kedua. Sedangkan sampel tidak berkolerasi (independent) antara dua kelompok, bila sampel-sampel yang menjadi objek penelitian dapat dipisahkan secara tegas, artinya anggota sampel kelompok pertama tidak ada yang menjadi anggota sampel kelompok kedua. Dalam penelitian ini metode analisis komparatif digunakan untuk menjawab hipotesis ketiga yang telah disajikan pada awal penelitian. Untuk mengetahui apakah hipotesis penelitian tersebut diterima ataupun ditolak dapat dilakukan dengan cara menghitung nilai $\mathrm{t}$ hitung dan $\mathrm{t}$ tabel perolehan dari hasil menguji rata-rata dan varian setiap variabel penelitian, sehingga dapat mengetahui apakah terdapat perbedaan nilai dari dua variabel penelitian. 


\section{Pembahasan}

Penulisan ini bertujuan untuk mengetahui bagaimana mutu Service system E-Commerce. Untuk mendapatkan data dan informasi tersebut digunakan angket/kuesioner, kemudian setelah data terkumpul diolah mengunakan SPSS (Statiscal Package for the Sciences). Selanjutnya untuk mengetahui gambaran masing-masing variabel digunakan analisis deskriptif demi menemukan data dan informasi yang lebih akurat mengenai penelitian ini.

\section{A. Nilai Tingkat Service Toko Online}

Untuk mengukur nilai tingkat service toko online dengan cara analisis deskriptif dimana metode menganalisis data dengan cara mendeskripsikan atau menggambarkan data yang telah dikumpulkan dengan tujuan untuk menjawab hipotesis yang telah disajikan pada awal penelitian sehingga dapat mengetahui apakah hipotesis dalam suatu penelitian diterima atau ditolak. Berikut ini akan disajikan data yang telah diperoleh dari masing-masing responden terhadap variabel yang diteliti untuk mengetahui gambaran dari masing-masing variabel dalam penelitian ini yaitu toko online. Hasil pengelolahan data dengan analisa deskriptif untuk masing-masing variabel yaitu Service akan dibahas satu persatu secara detail dan terperinci.

Variabel Service memiliki 10 buah indikator yang dibuat penulis menjadi 10 butir pernyataan. Untuk distribusi dan perhitungan skor dari olahan data, akan dijelaskan dalam tabel yang nantinya juga akan diperoleh presentase masing-masing butir pernyataan ataupun keseluruhan variabel yang pada akhirnya dapat berfungsi menjawab hipotesa deskriptif penelitian. Adapun detail nilai tingkat service toko online sebagai berikut:

1. Kelengkapan Informasi

Berdasarkan data yang didapat mengenai Kelengkapan informasi toko online menunjukan presentase sebesar $10,29 \%$ atau dengan skor keseluruhan sebanyak 1151 yang jika disimpulkan berada pada rentang kelas "Baik" (1026,7-1305,8).

\section{Inovasi produk}

Berdasarkan data yang didapat mengenai Inovasi produk toko online menyatakan bahwa presentase sebesar $10,33 \%$ atau dengan skor keseluruhan sebanyak 1155 yang jika disimpulkan berada pada rentang kelas "Baik" (1026,7-1305,8).

3. Cepat memproses pesanan

Berdasarkan data yang didapat mengenai Cepat memproses pesanan toko online menyatakan presentase sebesar 10,15\% atau dengan skor keseluruhan sebanyak 1135 yang jika disimpulkan berada pada rentang kelas "Baik" (1026,7-1305,8).

4. Tanggung jawabnya terhadap pesanan pelanggan

Berdasarkan data yang didapat mengenai Tanggung jawabnya terhadap pesanan pelanggan toko online menunjukkan presentase sebesar $10,07 \%$ atau dengan skor keseluruhan sebanyak 1126 yang jika disimpulkan berada pada rentang kelas "Baik" (1026,7-1305,8).

5. Kemudahan bertransaksi

Berdasarkan data yang didapat mengenai Kemudahan bertransaksi toko online menunjukkan presentase sebesar 10,31\% atau dengan skor keseluruhan sebanyak 1153 yang jika disimpulkan berada pada rentang kelas "Baik" (1026,7-1305,8).

6. Sistem keamanan terjamin

Berdasarkan data yang didapat mengenai Sistem keamanan terjamin toko online menunjukkan presentase sebesar 9,56\% atau dengan skor keseluruhan sebanyak 1069 yang jika disimpulkan berada pada rentang kelas "Baik" (1026,7-1305,8).

7. Jaminan mutu produk yang dikirimkan

Berdasarkan data yang didapat mengenai Jaminan mutu produk yang dikirimkan toko online menunjukkan presentase sebesar 9,74\% atau dengan skor keseluruhan sebanyak 1089 yang jika disimpulkan berada pada rentang kelas "Baik" (1026,7-1305,8).

8. Ketepatan pada waktu pengiriman

Berdasarkan data yang didapat mengenai Ketepatan pada waktu pengiriman toko online menunjukkan presentase sebesar 10,02\% atau dengan skor keseluruhan sebanyak 1121 yang jika disimpulkan berada pada rentang kelas "Baik" (1026,7-1305,8).

9. Respon pelayanan baik

Berdasarkan data yang didapat mengenai Respon pelayanan baik toko online menunjukkan presentase sebesar 9,71\% atau dengan skor keseluruhan sebanyak 1086 yang jika disimpulkan berada pada rentang kelas "Baik" (1026,7-1305,8). 
10. Memberikan solusi pelayanan dari permasalahan

Berdasarkan data yang didapat mengenai Memberikan solusi pelayanan dari permasalahan toko online menunjukan presentase sebesar 9,83\% atau dengan skor keseluruhan sebanyak 1099 yang jika disimpulkan berada pada rentang kelas “Baik” (1026,7-1305,8).

Adapun bahwa keseluruhan nilai tingkat service toko online menunjukkan presentase sebesar 64,09\% atau dengan skor keseluruhan sebanyak 1118,4 yang jika disimpulkan berada pada rentang kelas “Baik” (1026,7-1305,8).

Apabila ditinjau dari grafik nilai dari masing-masing indikator mempunyai nilai yang saling berdekatan atau hampir sama. Sedangkan nilai total skor yang paling tinggi terlihat pada Inovasi Produk yang lebih cepat didapat melalui toko online.

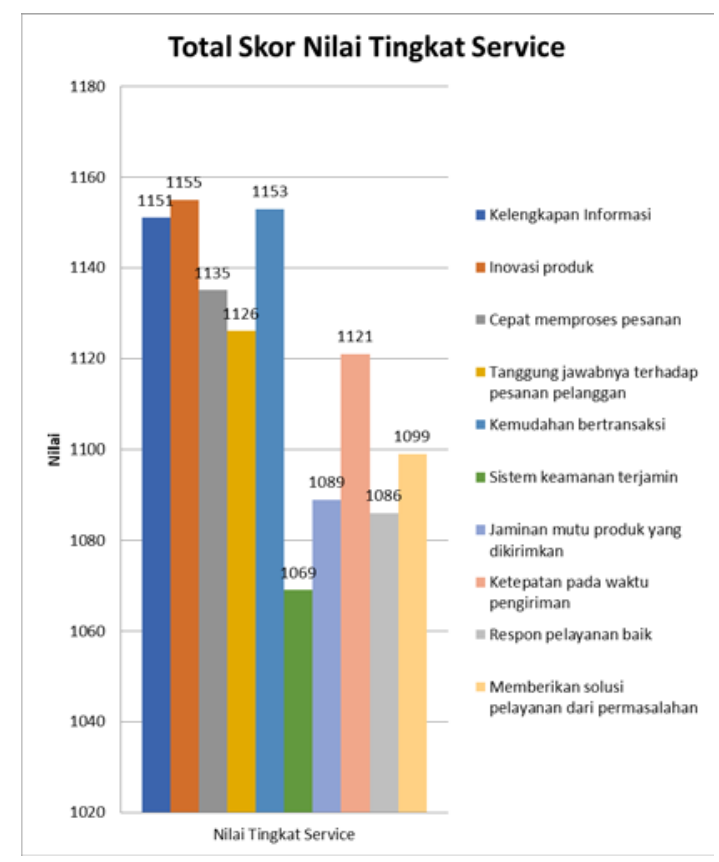

Gambar 4.3 Total Skor Nilai Tingkat Service

B. Analisis Perbandingan Perceived Performance

Untuk melakukan analisis perbandingan maka mengambil dua perbandingan dari toko online yang popular yaitu lazada.co.id dan Zalora.co.id. Sebelum uji perbandingan

Tabel 4.14 Hasil uji validitas pada toko online lazada.co.id dan zalora.co.id

\begin{tabular}{|c|c|c|c|c|}
\hline \multirow{2}{*}{ Instrumen } & \multicolumn{2}{|c|}{$\begin{array}{c}\text { Corrected Item-Total } \\
\text { Correlation (r-hitung) }\end{array}$} & $\begin{array}{c}\text { Product } \\
\text { Moment (r- tabel) }\end{array}$ & \multirow{2}{*}{ Keterangan } \\
\cline { 2 - 3 } & $\mathbf{X 1}$ & $\mathbf{X 2}$ & & \\
\hline 1 & 0.354 & 0.380 & & Valid \\
\hline 2 & 0.321 & 0.385 & & Valid \\
\hline 3 & 0.308 & 0.415 & & Valid \\
\hline 4 & 0.337 & 0.363 & & Valid \\
\hline
\end{tabular}

dibutuhkan dahulu uji validitas dan reliabilitas. Berdasarkan hasil analisis data diperoleh hasil sebagai berikut: 


\begin{tabular}{|c|c|c|c|c|}
\hline 5 & 0.252 & 0.411 & 0.105 & Valid \\
\cline { 3 - 3 } 6 & 0.258 & 0.313 & & Valid \\
\cline { 3 - 3 } & 0.235 & 0.343 & Valid \\
\hline 7 & 0.275 & 0.354 & & Valid \\
\hline 8 & 0.319 & 0.347 & & Valid \\
\hline 9 & 0.260 & 0.306 & & Valid \\
\hline 10 & & & \\
\hline
\end{tabular}

Berdasarkan tabel 4.14 di atas, hasil pengujian validitas toko online perbandingan pada website lazada.co.id menunjukkan nilai corrected item-total correlation untuk masingmasing instrumen hasil hitung (r-hitung) lebih besar dari pada nilai r-tabel yaitu nilai r-hitung $>$ 0,105 . Oleh karena itu, dapat disimpulkan bahwa seluruh instrumen dari variabel toko online pada website lazada.co.id dalam penelitian ini adalah valid.

Kemudian dilakukan Uji t-test digunakan untuk menguji hipotesis pada penelitian ini. Penggujian menggunakan uji dua sisi dengan tingkat kesalahan $\alpha=5 \%$ atau 0,05 dikarenakan uji dua sisi, maka nilai $\alpha / 2=0,05 / 2=0,025$. Kemudian dicari ttabel pada tabel distribusi $-\mathrm{t}$ dengan ketentuan $\mathrm{db}=\mathrm{n}-2=349-2=347$ sehingga $t(\alpha, d b)=t(0,025,347)=1,966$. Kriteria penggunakan pengujian ini adalah:

a. Bila -ttabel $\square$ thitung $\square$ ttabel, maka $\mathrm{H} 0$ diterima dan $\mathrm{H} 1$ ditolak.

b. Bila thitung $\geq$ ttabel maka H0 ditolak dan $\mathrm{H} 1$ diterima.

Tabel 4.15 Hasil uji Independent T-Test group

\begin{tabular}{|l|c|c|c|c|}
\hline \multicolumn{1}{|c|}{ ECommerce } & $\mathrm{N}$ & Mean & Std. Deviation & Std. Error Mean \\
\hline $\begin{array}{l}\text { Website Lazada.co.id } \\
\begin{array}{l}\text { Score } \\
\text { Website Zalora.co.id }\end{array}\end{array}$ & 349 & 32.05 & 4.623 & .247 \\
\hline
\end{tabular}

Dalam penelitian ini, uji t-test digunakan untuk menjawab hipotesis ke tiga, yaitu terdapat perbedaan penggunaan toko online pada website lazada.co.id dan website zalora.co.id.
H0: Tidak terdapat perbedaan penggunaan toko online pada website lazada.co.id dan website zalora.co.id.

H1: Terdapat perbedaan penggunaan toko online pada website lazada.co.id dan website zalora.co.id

Tabel 4.16 Hasil uji Independent T-Test Independent Samples Test

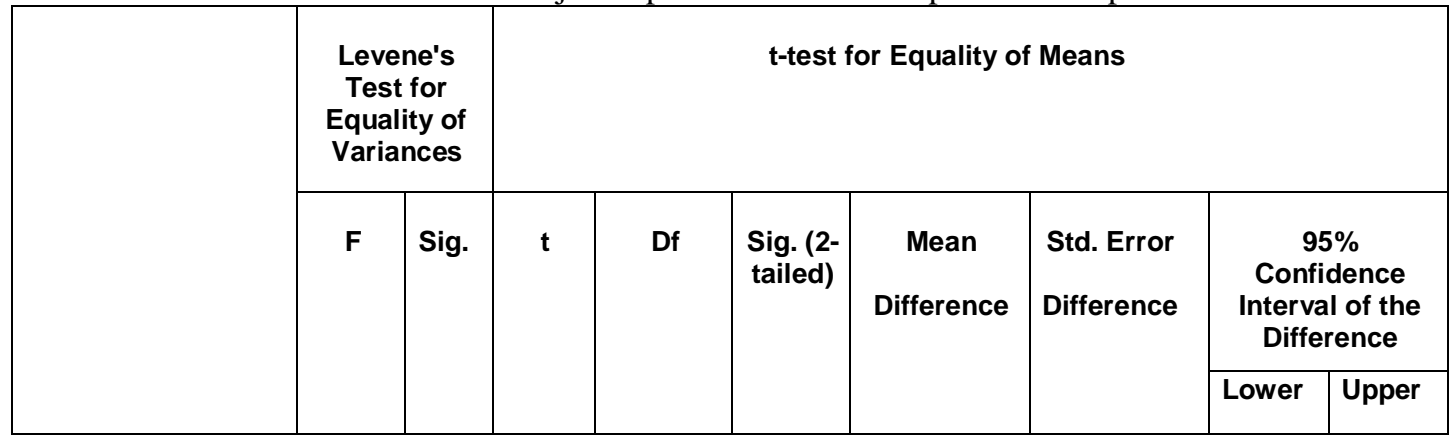




\begin{tabular}{|c|l|l|l|l|r|r|r|r|r|}
\hline $\begin{array}{l}\text { Equal } \\
\text { variances } \\
\text { assumed } \\
\text { Score } \begin{array}{c}\text { Equal } \\
\text { variances } \\
\text { not } \\
\text { assumed }\end{array}\end{array}$ & 4.444 & .035 & 5.731 & 696 & .000 & 2.097 & .366 & 1.379 & 2.816 \\
\cline { 2 - 9 } & & 5.731 & 690.928 & .000 & 2.097 & .366 & 1.379 & 2.816 \\
\hline
\end{tabular}

Berdasarkan tabel 4.16 di atas menunjukkan penggunaan toko online pada website lazada.co.id memperoleh nilai thitung = 5,731 dimana lebih besar dari t(tabel) sebesar 1,966 maka dapat diartikan bahwa H0 ditolak dan H1 diterima. Sehngga hasil dari analisis perbandingan berupa Terdapat perbedaan penggunaan toko online dengan pada website lazada.co.id dan website zalora.co.id

\section{Kesimpulan}

Penelitian ini bertujuan untuk penilaian tingkat Service Toko Online dan Analisis Perbandingan Perceived Performance. Dari rumusan masalah penelitian yang diajukan, maka analisis data yang telah dilakukan dan pembahasan yang telah dikemukakan pada bab sebelumnya, dapat ditarik beberapa kesimpulan dari penelitian ini adalah sebagai berikut: (1)Keseluruhan nilai tingkat service toko online menunjukkan menunjukkan presentase kepuasan sebesar 64,09\%. Sedangkan nilai tingkat berdasarkan kelengkapan informasi, inovasi produk, cepat memproses pesanan, tanggung jawabnya terhadap pesanan pelanggan, kemudahan bertransaksi, sistem keamanan terjamin, jaminan mutu produk yang dikirimkan, ketepatan pada waktu pengiriman, respon pelayanan baik, memberikan solusi pelayanan dari permasalahan bernilai baik. (2)Hasil dari analisis perbandingan perceived performance terdapat perbedaan masing-masing penggunaan toko online dengan contoh pada website lazada.co.id dan website zalora.co.id. Isi perceived performance mengacu pada performance atau capaian dari tingkat service yang diberikan kepada konsumen. Perbedaan perceived performance berbeda karena masingmasing toko online mempunyai fitur yang berbeda-beda dan waktu pemrosesan yang berbeda.

\section{Ucapan Terima Kasih}

Terimakasih kepada LPPM Universitas Putera Batam sebagai Lembaga yang membantu pengembangan penelitian.

\section{Daftar Pustaka}

[1] P. Nugroho, W. W. Winarno, and R. Hartanto, "Faktor-faktor yang mempengaruhi niat menggunakan mobile payment dengan pendekatan extended the unified theory of acceptance and use of technology," CITEE Dep. Tek. Elektro dan Teknol. Informasi, FT UGM, pp. 226-233, 2017.

[2] A. Andhini, "Pengaruh Transaksi Online Shopping, Dan Kepercayaan Konsumen Terhadap Kepuasan Konsumen Pada ECommerce,” J. Ilmu dan Ris. Manaj., vol. 6, no. 7, pp. 1-23, 2017.

[3] I. A. Wardoyo, "Faktor- faktor yang berpengaruh terhadap keputusan pembelian secara online pada mahasiswa universitas Gunadarma,” Ekon. Manaj. Sumber Daya, vol. 19, p. 13, 2017.

[4] C. E. Franco and R. S. Bulomine, "Advantages And Challenges Of Ecommerce Customers And Businesses: In Indian Perspective," Int. J. Res. Granthaalayah, vol. 4, no. 3, p. 7, 2016.

[5] M. Palak Gupta and A. Dubey, "ECommerce-Study of Privacy, Trust and Security from Consumer's Perspective," Int. J. Comput. Sci. Mob. Comput., vol. 56, no. 6, pp. 224-232, 2016.

[6] M. Pradana, "Klasifikasi Bisnis ECommerce di Indonesia," Modus, vol. 27, no. 2, pp. 163-174, 2015.

[7] R. Nuzulahka, "SISTEM PELAYANAN DAN PEMESANAN ONLINE,” $J$. String, vol. 2, no. 3, pp. 274-281, 2018.

[8] C. Serrano-Cinca, Y. Fuertes-Callén, and 
C. Mar-Molinero, "Measuring DEA efficiency in Internet companies,” Decis. Support Syst., vol. 38, no. 4, pp. 557573, 2005.

[9] M. H. Moshrefjavadi, H. Rezaie Dolatabadi, M. Nourbakhsh, A. Poursaeedi, and A. Asadollahi, "An Analysis of Factors Affecting on Online
Shopping Behavior of Consumers," Int. J. Mark. Stud., vol. 4, no. 5, 2012.

[10] E. V. Pogorelova, I. V. Yakhneeva, A. N. Agafonova, and A. O. Prokubovskaya, "Marketing mix for e-commerce," Int. J. Environ. Sci. Educ., vol. 11, no. 14, pp. 6744-6759, 2016. 